\title{
COMMENTS
}

\section{Enforcing State Domestic Relations Decrees in Federal Courts}

Federal courts have traditionally refused to hear diversity cases that fall under the heading of domestic relations. ${ }^{1}$ This exception to diversity jurisdiction has its roots in nineteenth-century decisions that held that federal courts would not make original grants of divorce, separation, alimony, or support. ${ }^{2}$ In this century the exception has grown unevenly. While the nineteenth-century cases support at most the claim that federal courts will not make original grants, ${ }^{3}$ some federal courts have in recent years refused to enforce state decrees of alimony, ${ }^{4}$ support, ${ }^{6}$ and custody. ${ }^{6}$ Other courts have questioned the very existence of the exception. ${ }^{7}$

The aim of this comment is to investigate the power of federal

1 Little has been written about the domestic relations exception to diversity jurisdiction. For examples of this scarce literature, see Vestal \& Foster, Implied Limitations on the Diversity Jurisdiction of Federal Courts, 41 MinN. L. REv. 1, 23-36 (1956); Note, Federal Jurisdiction of "Domestic Relations" Cases, 7 J. FAM. L. 309 (1967); 7 RuT.-CAM. L.J. 593 (1976). For a general background, see also P. Bator, P. Mishkin, D. Shapiro \& H. Wechsler, Hart and Wechsler's The Fedgral Courts and the Federal System 1189-92 (2d ed. 1973) [hereinafter cited as Hart \& WeChsLBR]; C. Wright, A. Minler \& E. Coopre, 13 Frderal Practicb and Procrdurg $\S 3609$ (1975). Note, The Domestic Relations Exception to Diversity Jurisdiction, 83 CoLum. L. REv. 1824 (1983), which was published while the present article was in press, would deny federal jurisdiction in most divorce and in all custody cases.

2 Most courts that have addressed the problem have spoken of a lack of jurisdiction, traceable perhaps to limits on the jurisdiction of English courts of equity at the time of the adoption of the Constitution. See Vestal \& Foster, supra note 1, at 28-31. Other courts have spoken instead of a doctrine of abstention. See Spindel v. Spindel, 283 F. Supp. 797, 811-12 (E.D.N.Y. 1968). For a critical discussion of the historical account, see Lloyd v. Loeffler, 694 F.2d 489, 491-92 (7th Cir. 1982); Phillips, Nizer, Benjamin, Krim \& Ballon v. Rosenstiel, 490 F.2d 509, 512-14 (2d Cir. 1973); Spindel, 283 F. Supp. at 802-09.

s See infra notes 12-33 and accompanying text.

- See, e.g., Morris v. Morris, 273 F.2d 678 (7th Cir. 1960).

- See, e.g., Albanese v. Richter, 161 F.2d 688 (3d Cir.), cert. denied, 332 U.S. 782 (1947).

- See infra notes 37-42 and accompanying text.

T See, e.g., Spindel v. Spindel, 283 F. Supp. 797, 806 (E.D.N.Y. 1968). 
courts to enforce state decrees. ${ }^{8}$ The power of federal courts to make original grants, though not indefensible, is not at issue here. In general, federal courts have been reluctant to enforce alimony, custody, and support decrees. The main reason for this reluctance has been a desire to avoid complicated investigations into domestic conditions. Such investigations are said to intrude on state interests and to exceed the fact-finding capacity of federal courts. ${ }^{9}$

No court has articulated the connection between the enforcement of state decrees and the investigations they are said to entail. The essential link appears to be the modifiability of most decrees. A federal court that modified a state decree when enforcing it would indeed be required to make the same detailed investigations involved in an original decree. Thus, where enforcement is inextricably bound up with a decree's modification, federal courts should refuse jurisdiction. Where enforcement without modification is possible, however, federal courts should entertain actions to enforce state decrees. Where jurisdiction is correctly declined, it will be for reasons of due process and federalism, but this comment will argue that those considerations apply only in certain well-defined areas and that, for the most part, it is within the competence of the federal courts to enforce state decrees of alimony, support, and custody. The comment will also argue that the recent trend toward enforcement of custody decrees through large tort awards is inefficient and that in any event damage awards are only justified in cases in which direct enforcement would be justified as well.

\section{The Development of the Exception}

The beginnings of the domestic relations exception lie in a

s The comment does not consider whether there ought to be such a thing as diversity jurisdiction; it assumes that federal courts will continue to entertain diversity cases and attempts to set out the scope of a principled exception to that jurisdiction in cases involving domestic relations. On the question of the reasonableness of diversity jurisdiction, see $\mathrm{H}$. Friendly, Federal Jurisdiction: A General View 139-52 (1973).

- The reasoning criticized here is similar to that used by Judge Learned Hand to uphold the penal and tax exceptions to full faith and credit: (1) a state will not enforce liabilities arising in another state if they conflict with its own public policy, and thus enforcement presupposes scrutiny of the liability; (2) but scrutiny may commit the domestic state to a position that would embarrass its neighbor; hence (3) no enforcement of sister state tax or penal judgments. See Moore v. Mitchell, 30 F.2d 600, 604 (2d Cir. 1929) (L. Hand, J., concurring), aff'd, 281 U.S. 18 (1930). Here again the crucial step is the first one; it is not clear why absence of scrutiny should bar enforcement. See Oklahoma ex rel. Oklahoma Tax Comm'n v. Neely, 225 Ark. 230, 232, 282 S.W.2d 150, 151 (1955) ("In our opinion the oftrepeated dogma, that one sovereign does not enforce the revenue laws of another, is rapidly approaching a deserved extinction ....”.). 
group of nineteenth-century cases concerning jurisdiction over the enforcement of custody and alimony decrees. These cases culminate in In re Burrus, ${ }^{10}$ the case most often cited for the proposition that federal courts do not have jurisdiction over domestic relations. ${ }^{11}$ A careful reading of these cases will show how little support they give to the current broad interpretation of the exception.

\section{A. Early Cases}

In the nineteenth century a number of suits were brought in federal courts by distraught parents seeking by means of a writ of habeas corpus to get the question of the custody of a child before the courts. In a number of the earlier cases there was no state custody decree to be enforced, and the federal courts divided on the extent of their authority to make original grants of custody. While one court declared that there was such authority, ${ }^{12}$ others declined jurisdiction because of a failure of amount in controversy, saying that either the writ or the custody itself lacked monetary value. ${ }^{13}$ Still another held that while the disposition of custody is a common-law power of the sovereign, the federal courts have "no . . . common law prerogatives . . . which can be exercised without authority of . . . law."14

The issue of enforcement of custody decrees already granted by a state finally arose in Bennett $v$. Bennett. ${ }^{15}$ Since the court was being asked to enforce an existing decree, it did not need to consider whether it had the authority to award custody. The court founded jurisdiction upon diversity and, as to the amount in con-

10136 U.S. 586 (1890).

1I See, e.g., Hernstadt v. Hernstadt, 373 F.2d 316, 317 (2d Cir. 1967).

12 See United States v. Green, 26 F. Cas. 30, 31 (C.C.D.R.I. 1824) (No. 15,256) ("When . . . the court is asked to lend its aid to put the infant into the custody of the father, and to withdraw him from other persons, it will look into all the circumstances, and ascertain whether it be for the real, permanent interests of the infant . . . ."). There was no real holding in this case, since the outcome was a settlement approved by the court. Id. at 32 .

18 See, e.g., Barry v. Mercein, 46 U.S. (5 How.) 103, 120 (1847) (not sufficiently determinable amount in controversy to bring the matter before the Supreme Court on appeal; the Court did not decide whether the lower court had jurisdiction); Ex parte Everts, 8 F. Cas. 909, 914 (C.C.S.D. Ohio 1858) (No. 4581) (diversity jurisdiction does not include proceedings by habeas corpus "for the plain reason, if there were no other, that the matter in controversy has no pecuniary value, and can not be estimated in money"). The Court in Barry said that the matter of custody "rises superior to money considerations." 46 U.S. (5 How.) at 120.

14 In re Barry, 42 F. 113, 119 (C.C.S.D.N.Y. 1844).

1s 3 F. Cas. 212 (D.C.D. Or. 1867) (No. 1318) [hereinafter cited as Bennett I]. 
troversy, held that custody satisfied that requirement. ${ }^{16}$

The most important early case cited for the rule that federal courts should stay out of domestic controversies is Barber v. Barber. ${ }^{17}$ The plaintiff in Barber had obtained a judgment in the New York Court of Chancery against the defendant for the payment of alimony ${ }^{18}$ and sued in the United States District Court for the District of Wisconsin to enforce the prior judgment. ${ }^{19}$ On the defendant's appeal, the Supreme Court first set the stage with the following dictum:

Our first remark is-and we wish it to be remembered-that this is not a suit asking the court for the allowance of alimony. That has been done by a court of competent jurisdiction. ...

We disclaim altogether any jurisdiction in the courts of the United States upon the subject of divorce, or for the allowance of alimony, either as an original proceeding in chancery or as an incident to divorce.....20

The court went on to hold that the district court acting as a court of equity had subject-matter jurisdiction to enforce the New York alimony judgment. ${ }^{21}$ Nonetheless, the disclaimer of jurisdiction to decree divorce or grant alimony has, despite the holding, become the fountainhead of the general domestic relations exception. ${ }^{22}$

16 The court stated:

If it was thought proper and right by the framers of the constitution and congress [sic] to give the national courts jurisdiction of a controversy between citizens of different states, where the matter in dispute is mere rights of property-to be measured by mere dollars and cents-why should their jurisdiction not extend to the more important controversy like this, where the matter in dispute is the custody and control of an infant child of the parties.

Id. at 220.

Bennett $I$ was the last major case on custody prior to the Supreme Court ruling in Burrus. There was, however, an annotation on habeas corpus appended to In re Brosnahan, 18 F. 62, 74-75 (C.C.W.D. Miss. 1883), in which the author, conceding an apparent split in the courts on this matter, argued against jurisdiction to issue writs of habeas corpus in custody cases solely on the ground that there was no amount in controversy, as required by diversity jurisdiction. He did not distinguish custody cases based on state decrees from attempts to have original determinations of custody made in the federal courts.

1762 U.S. (21 How.) 582 (1859).

18 Id. at $584-85$.

10 Id. at 583-84.

20 Id. at 584.

21 Id. at 588, 591-92.

22 See, e.g., Spindel v. Spindel, 283 F. Supp. 797, 800-803 (E.D.N.Y. 1968). A later case, Terry v. Sharon, 131 U.S. 40 (1889), also took jurisdiction in a case involving domestic relations. The Terry Court was required to decide whether the United States Circuit Court for the Northern District of California had jurisdiction to void a written declaration of marriage 


\section{B. In re Burrus}

Prior to Burrus, although the lower federal courts divided over jurisdiction of original custody decrees, both the lower courts and the Supreme Court enforced existing state decrees of custody and alimony. Burrus is cited for the first actual holding of the domestic relations exception (which appeared as dictum in Barber), ${ }^{23}$ and for the extension of that doctrine to custody cases. ${ }^{24}$ Neither can be found in the opinion.

In Burrus, the effect of a domestic relations exception on custody cases was considered but not decided. A careful reading of the case reveals that the opinion has little to do with the position that later courts have read into it. Although the Court did say that any question of domestic relations belonged to state, not federal, law, ${ }^{25}$ the court intended by the statement to indicate the limits of federal legislative power, not the limits of the jurisdiction of federal courts.

The petitioner, T.F. Burrus, was being held in prison for contempt by order of the United States District Court for the District of Nebraska, having abducted his grandchild after turning her over to her father upon the district court's order. The district court had considered the question of its own jurisdiction and had decided that question in the affirmative. ${ }^{26}$ In its own consideration of the lower court's jurisdiction, the Supreme Court pointed out that jurisdiction in federal courts must have some specific basis. ${ }^{27}$ First, the Court ruled out any constitutional question as a basis for jurisdiction, since there was no evidence that in the grandfather's care the child was deprived of any liberty guaranteed by the Constitution. ${ }^{28}$ The Court then ruled out any infraction of a federal statute: "[t]he whole subject of the domestic relations of husband and wife, parent and child, belongs to the laws of the States and not to the laws of the United States."29 Turning to the diversity basis for ju-

between the defendant and the plaintiff's decedent. On appeal the defendant argued, citing Barber, id. at 42 , that the suit to cancel the declaration was but "an attempt, by slightly disguised indirection, to accomplish a divorce which the court recognized it had no power to accomplish directly." Id. at 44. The Court held that the circuit court could hear the suit, since "the object of the suit, the cancellation of a forged instrument, is one of the common heads of equity jurisdiction." Id. at 48.

${ }^{2 s}$ See 62 U.S. (21 How.) at 584.

24 See, e.g, Hernstadt v. Hernstadt, 373 F.2d 316, 317 (2d Cir. 1967).

25136 U.S. 586, 593-94 (1890).

$26 \mathrm{Id}$. at 588.

27 Id. at 591 .

28 Id. at 593.

20 Id. at 593-94. Thus what is intended to be ruled out by these words is not jurisdic- 
risdiction, which the opinion is sometimes said to have decided, ${ }^{30}$ the Court stated:

[W] hether the diverse citizenship of parties contesting this right to the custody of the child could, in the courts of the United States, give jurisdiction to those courts to determine that question, has never been decided by this Court that we are aware of. Nor is it necessary to decide it in this case, for the order ... is not a judgment of the Circuit Court of the United States, but a judgment of the District Court of the same District ... [ [and] the District Courts of the United States have not jurisdiction by reason of the citizenship of the parties. $^{31}$

Thus, in the absence of any federal question, "the . . . proceeding before the . . . District Court was coram non judice . . . ."32

Concerning a number of crucial issues, the holding in Burrus evidently says nothing. The Court did not address the difference, for jurisdictional purposes, between original grants of custody and the enforcement of state grants; there was no state decree in the case before it. And the question whether there is a domestic relations exception, and whether it extends to custody, is precisely the question the Court found it unnecessary to decide. ${ }^{33}$

\section{Twentieth-Century Developments}

Despite the meagerness of the exception under nineteenthcentury precedent, and despite the lack of any precedent for including suits seeking to enforce state decrees in the exception, the exception has grown in the twentieth century. The principles that have guided development of the exception in the area of enforcement are difficult to discern. In some of the cases in which enforcement of alimony and support decrees have been at issue, federal

tion of federal courts over domestic relations cases, but rather the power of the federal legislature to legislate in these matters.

so See, e.g., Ohio ex rel. Popovici v. Agler, 280 U.S. 379, 383 (1930).

s1 136 U.S. at 596 (emphasis added). Though most of the nineteenth-century federal district courts did not have diversity jurisdiction, in Bennett $I$ and Barber the district courts did. See Judiciary Act of 1789, $\S \S 9,11,1$ Stat. 73, 76, 78. The United States District Courts for the District of Oregon and the District of Wisconsin, like the United States District Court for the District of Kentucky under the original Judiciary Act of 1789, id. § 10, 1 Stat. 73, 77, had many of the prerogatives of federal circuit courts, including diversity jurisdiction.

32136 U.S. at 597.

3s See Hart \& WechsLer, supra note 1, at 1189. 
courts have found jurisdiction. ${ }^{34}$ The Fourth Circuit, for example, has twice ordered lower courts to enforce state decrees. ${ }^{36}$ On the other hand, some federal courts have refused to enforce alimony and support decrees. ${ }^{36}$ And in spite of Bennett $I$, federal courts have almost uniformly refused to enforce custody and visitation decrees. $^{37}$

Perhaps the most significant development has been in a line of recent cases in which plaintiffs sought both enforcement of a custody decree and damages in tort for the abduction of the child..$^{38}$ In a 1973 case, the Sixth Circuit denied that it had jurisdiction over either claim, ${ }^{39}$ and in 1981, the First Circuit abstained from taking jurisdiction in a similar case. ${ }^{40}$ In 1982 , however, the District of Columbia and Seventh Circuits divided the claims in similar suits. Both granted the jurisdiction of the district court to award damages, but the District of Columbia Circuit refused to enforce the custody decree by injunction, ${ }^{41}$ and the Seventh Circuit intimated that the district court was without jurisdiction to levy continuing punitive damages for the continuance of the tort. ${ }^{42}$

\section{Policies Affecting the Enforcement of MODIFIABLE Decrees}

Despite the weakness of the nineteenth-century precedents, ${ }^{\text {s }}$ federal courts justify the present vitality of the domestic relations exception with a number of policy considerations. In Crouch $v$.

34 See, e.g., Jagiella v. Jagiella, 647 F.2d 561 (5th Cir. 1981); Keating v. Keating, 542 F.2d 910 (4th Cir. 1976); Harrison v. Harrison, 214 F.2d 571 (4th Cir.), cert. denied, 348 U.S. 896 (1954).

ss See Keating, 542 F.2d at 912; Harrison, 214 F.2d at 573. Modification was left to the state court that issued the original decree, " such change to be thereafter adopted by this Court.' "Id. at 573 (quoting district court's decree).

${ }^{36}$ See, e.g., Gonzales v. Gonzales, 83 F. Supp. 496 (E.D. Pa. 1949).

${ }^{37}$ See, e.g., Lloyd v. Loeffler, 694 F.2d 489 (7th Cir. 1982); Bennett v. Bennett, 682 F.2d 1039 (D.C. Cir. 1982) [hereinafter cited as Bennett II] (unrelated to Bennett I of 1867); Hernstadt v. Hernstadt, 373 F.2d 316 (2d Cir. 1967); Cherry v. Cherry, 438 F. Supp. 88 (D. Md. 1977); Gill v. Gill, 412 F. Supp. 1153 (E.D. Pa. 1976), aff'd, 568 F.2d 768 (3d Cir. 1978).

ss E.g., Wasserman v. Wasserman, 671 F.2d 832 (4th Cir. 1982), cited with approval in Bennett II, 682 F.2d at 1042.

30 See Gargallo v. Gargallo, 472 F.2d 1219 (6th Cir.), cert. denied, 414 U.S. 805 (1973).

to See Sutter v. Pitts, 639 F.2d 842, 843 (1st Cir. 1981) ("[A]lthough the exception has been narrowly confined, we, and other courts of appeals, have held that federal courts should abstain from adjudicating claims that are closely related to, though not within, the jurisdictional exception." (citations omitted)).

41 See Bennett II, 682 F.2d at 1040-41.

42 See Lloyd v. Loeffler, 694 F.2d at 494 (dictum).

13 See supra notes $10-33$ and accompanying text. 
Crouch, ${ }^{44}$ for example, these considerations are summarized:

The reasons for federal abstention in these cases are apparent: the strong state interest in domestic relations matters, the competence of state courts in settling family disputes, the possibility of incompatible federal and state court decrees in cases of continuing judicial supervision of the state, and the problem of congested dockets in federal courts. ${ }^{45}$

These four considerations are not equally relevant to the justification of the exception. The problem of congested dockets, for example, may be pressing, and may even be a reason for eliminating diversity jurisdiction entirely. ${ }^{48} \mathrm{It}$ is not by itself a justification for cutting back in any particular area. Crowded dockets provide no more than an additional reason to remove an area from diversity jurisdiction if it can be excluded on other grounds. And where there is a genuine possibility of incompatible results, the federal courts may abstain from consideration of the particular case, in domestic relations as in any other area. ${ }^{47}$

While special competence and interest are more directly relevant to the domestic relations exception in particular, the connection between these considerations and the jurisdiction of federal courts is not self-evident. Conceding state interest in making the original grants, it must surely be in the state's interest to have the grant enforced in other courts. ${ }^{48}$ And even granting the lack of competence of federal courts to make detailed investigations of domestic conditions, it still remains to be shown that such investigations are necessary to the enforcement of decrees.

The connection between enforcement and state interests on the one hand and enforcement and competence to carry out investigations on the other depend upon the modifiability of state decrees. It is not enforcement that infringes on state interest; it is

44566 F.2d 486 (5th Cir. 1978).

45 Id. at 487 (citations omitted). See also Lloyd v. Loeffler, 694 F.2d at 492 (7th Cir. 1982) (federal courts not competent to handle domestic relations cases); Buechold v. Ortiz, 401 F.2d 371, 373 (9th Cir. 1968) (lack of competence, state interest, comity); Cherry v. Cherry, 438 F. Supp. 88, 90 (D. Md. 1977) (lack of competence, state interest); Thrower v. Cox, 425 F. Supp. 570, 573 (D.S.C. 1976) (workload, state interest); Zimmerman v. Zimmerman, 395 F. Supp. 719, 721 (E.D. Pa. 1975) (lack of competence).

is See, e.g., H. FrIEndLy, supra note 8, at 3 ("[T]he inferior federal courts, and indeed the Supreme Court as well, are faced with the prospect of a breakdown. . . [T] [Te inferior courts now have more work than they can properly do . . . .").

47 See cases cited supra note 2. See generally Vestal \& Foster, supra note 1.

48 This is the import of the Uniform Child Custody Jurisdiction Act, 9 U.L.A. 111 (1979) [hereinafter cited without cross-reference as U.C.C.J.A.]; see infra text following note 101. 
modification. Modification of an existing decree is as much of an intrusion into areas of state interest as the original grant of a decree would be. If federal courts cannot make an original grant, they cannot replace an existing decree with a new one. And it is modification, not mere enforcement, that calls for detailed investigations. What underlies the two policy considerations is a perceived connection between enforcement and modification: where there is enforcement there must be a hearing-or the possibility of a hearing-on modification. ${ }^{49}$ Modification intrudes on state interests in domestic relations and requires investigations, and investigations call into question the fact-finding competence of federal courts.

The courts that have refused enforcement have not articulated the connection between enforcement and modification very carefully. Where a modifiable decree granting alimony, support, or custody of a child may be enforced in whole or in part without prejudice to a party's right under the decree to seek modification by a state court, federal courts should have jurisdiction to enforce it. The limits beyond which a modifiable decree may not be enforced without prejudice to its modifiability are set by the two concerns of due process and federalism. Granting that the federal courts do not have the resources to make detailed investigations of domestic conditions, and hence are incompetent to modify state domestic relations decrees, a federal enforcement decree that prejudices the right of a party to a hearing on the modifiability of the original decree violates that party's right to due process under Griffin $v$. Griffin. ${ }^{50}$ Similarly, where enforcement affects modifiability, the federal courts have altered the substantive rights of the parties under state law, contrary to Erie Railroad $v$. Tompkins. ${ }^{51}$

The remainder of this comment will examine the limits set by due process and federalism on the enforcement of variously modifiable state decrees in federal courts, treating first awards of alimony and support and then custody decrees. It will conclude that only comparatively rare instances require the federal courts to deny jurisdiction over enforcement actions.

49 See Phillips, Nizer, Benjamin, Krim \& Ballon v. Rosenstiel, 490 F.2d 509, 514 (2d Cir. 1973) ("We have upheld federal jurisdiction in $\mathrm{a}[\mathrm{n}]$. . . action to determine whether a Connecticut divorce decree was invalid ... [and] in a[n] . . . action to declare a Mexican divorce invalid . . . . [But a] different view has been taken where the amounts ordered to be paid as alimony were subject to modification . . . ." The court clearly assumes that enforcement might entail modification in such cases.).

so 327 U.S. 220, 228 (1946). See infra text accompanying notes 53-74.

${ }^{31} 304$ U.S. 64 (1938). See infra text accompanying notes 74-80. 


\section{Modifiability, Due Process, and Federalism}

Decrees awarding alimony or support vary in their degree of modifiability. A decree may not be modifiable at all; it may be prospectively modifiable; it may be both prospectively and retrospectively modifiable. If it is not modifiable at all, then the amount due at each interval will be fixed, and there will be no way to change any feature of the decree. If a decree is prospectively modifiable only, then the terms of the decree can be changed, but the changes will apply to future installments only. A decree that is retrospectively modifiable can be changed even with respect to payments that have already come due..$^{52}$ In addition a decree may or may not have been reduced to judgment in the state that granted it, further complicating the decree's procedural posture. The following sections will explore the implications of due process and federalism for each of these various procedural permutations.

\section{A. Federal Enforcement and Due Process}

1. Griffin v. Griffin and Modifiable Decrees. To enforce a modifiable decree without allowing the defendant to be heard on the issue of modification may be a denial of due process under a line of Supreme Court cases arising under the full faith and credit clause $e^{\text {ts }}$ and culminating in Griffin v. Griffin. ${ }^{\mathbf{5}}$ These cases concern suits to enforce alimony and support decrees in courts of states other than those granting the original decrees, rather than in federal courts, as in Barber. ${ }^{\mathrm{BS}}$ Lynde v. Lynde, ${ }^{\mathrm{Bb}}$ the first such case, concerned a

32 For an example of a court treating a decree as retrospectively modifiable under state law, see Lynde v. Lynde, 181 U.S. 183 (1901). In Lynde, no alimony had been requested with the divorce decree. Later, after the husband had remarried, the wife asked the court to change the decree retrospectively to include alimony. The court complied, and the husband found himself with a liquidated obligation for all payments that would have accrued from the time of the original decree to the time of the modified decree.

ss "Full Faith and Credit shall be given in each State to the public Acts, Records and judicial Proceedings of every other State. And the Congress may by general Laws prescribe the Manner in which such Acts, Records and Proceedings shall be proved, and the Effect thereof." U.S. CoNST. art. IV, \& 1. Similarly, 28 U.S.C. \& 1738 (1976) provides that the

records and judicial proceedings of any court of any . . . State, Territory or Possession ... or copies thereof, so authenticated, shall have the same full faith and credit in every court within the United States and its Territories and Possessions as they have by law or usage in the courts of such State, Territory, or Possession from which they are taken.

${ }^{54} 327$ U.S. 220, 228 (1946). See also Hernstadt v. Hernstadt, 373 F.2d 316, 318 (2d Cir. 1967) (noting that "if the original judgment is subject to modification, the demands of full faith and credit may be satisfied whether or not the terms of the original decree are obeyed").

${ }^{\text {ss }} 62$ U.S. (21 How.) 582 (1859). See supra text accompanying notes 17-22. 
past-due alimony claim that was divisible into two parts; one amount had been reduced to judgment in the granting state, and the other amount, having accrued since the time of judgment, had not. ${ }^{57}$ The Court held that enforcement of a claim for the former amount was required in the sister state, but enforcement of a claim for the latter amount was not. ${ }^{58}$ This decision seemed to conflict with Barber, where installments that were past due but not reduced to judgment were held enforceable by the federal court. ${ }^{58}$ Under the Barber holding, the second claim in Lynde should have been enforceable.

In Sistare v. Sistare ${ }^{80}$ the Court undertook to reconcile the two rulings. It said that the Lynde court had believed, perhaps mistakenly, that in New Jersey past-due payments reduced to judgment were not retrospectively modifiable, but that past-due payments not reduced to judgment were always retrospectively modifiable. ${ }^{61}$ The Sistare Court interpreted Lynde as holding that if past-due amounts can be modified or recalled retrospectively under the law of the granting state, then sister states need not enforce the payment of those amounts under the full faith and credit clause. ${ }^{62}$

Barber, Lynde, and Sistare all discussed situations where a court need not enforce a decree of a foreign state court. In Griffin the Court addressed the question of when a court must not enforce such a decree. It held that if modifiable past-due obligations are enforced in any court, failure to give the defendant the opportunity he would be given in the first state to litigate the issue of modification is a denial of due process. ${ }^{63}$

This holding restricts the obligations that may be enforced in foreign courts. If a court, for whatever reason, cannot allow litigation of the issue of modification, no judgment that remains modifiable may be enforced. Conversely, where a judgment is no longer modifiable, Griffin presents no obstacle to enforcement. For example, a court may enforce claims for past-due payments under a ret-

se 181 U.S. 183 (1901).

s7 Id. at 187.

se See id.

so See 62 U.S. (21 How.) 582, 590-91 (1859) ("[C]ourts of equity will interfere to compel the payment of alimony ... . The interference, however, is limited to cases in which alimony has been decreed; then only to the extent of what is due . . ..").

218 U.S. 1 (1910).

il Id. at 16, 17 .

a2 Id.

es 327 U.S. at 228 . Griffin involved a retrospectively modifiable decree; the past-due payments were still modifiable. Id. at 226 . 
rospectively modifiable decree if they are already reduced to a nonmodifiable judgment, or enforce a decree that was originally nonmodifiable. Payments under a prospectively modifiable decree that are past due are also no longer modifiable by any court. Thus if a claim for the amount due is enforced, the defendant cannot argue that the court's judgment concerns an amount he still has the right to modify. Where a decree is retrospectively modifiable, enforcement of past-due payments will involve amounts that the defendant retains the right to change, and enforcement without a hearing on modification is a denial of due process; where the decree is prospectively modifiable, there is no analogous right, and no corresponding denial of due process, if the defendant is denied a hearing on modification of past-due amounts. ${ }^{64}$

2. Enforcement of Future Payments Under Prospectively Modifiable Decrees. In 1954 the Fourth Circuit affirmed the order of a district court enforcing both past-due and future installments under a decree that could only be modified prospectively. ${ }^{65}$ The district court had left modification to the state court, "such change thereafter to be adopted by this Court.." In Keating $v$. Keating, ${ }^{67}$ the Fourth Circuit reversed the ruling of a district court to the effect that, although it had the power to enforce claims for prospective payments, it had no obligation to do so. ${ }^{68}$ These holdings stand for the proposition that present enforcement even of prospectively modifiable future obligations may, in some circumstances, not be denial of due process, even though litigation of modification is not possible. ${ }^{69}$

Whether or not enforcement by federal courts of future payments under prospectively modifiable decrees violates the payor's due-process right to a hearing depends on the method of enforcement used. Enforcement of such claims can take one of two general forms. First, a court can levy a bond to guarantee future payments. ${ }^{70}$ By means of the bond, the court requires the defendant to

*4 It may be argued that even when a retrospectively modifiable decree is enforced by a federal court, the defendant could protect his rights in a subsequent modification hearing in the state court. Evidently that did not impress the Griffin court as sufficient protection.

${ }^{\text {Bs }}$ See Harrison v. Harrison, 214 F.2d 571 (4th Cir.), cert. denied, 348 U.S. 896 (1954).

${ }^{68}$ Id. at 573.

67 542 F.2d 910 (4th Cir. 1976).

${ }^{68}$ Id. at $911-12$.

${ }^{60}$ See also Morris v. Morris, 273 F.2d 678 (7th Cir. 1960) (decrees that are retrospectively modifiable will not be enforced, but those that are not will be). But see Walker v. Walker, 509 F. Supp. 853 (E.D. Va. 1981) (alimony decree is not enforceable in federal court when it is for an indefinite period and increasing amount).

${ }^{\text {zo }}$ This remedy was sought by the plaintiff and awarded by the trial court in Lynde, 181 
guarantee payment of a sum that he retains the right to modify under state law. Under the analysis set forth in Griffin, ${ }^{71}$ enforcement of future payments by bond violates the defendant's due process right to a modification hearing.

The second form of enforcement of claims for future payments is to enjoin the defendant to pay them, subject to punishment for contempt of court on failure to pay. ${ }^{22}$ Strictly speaking, the court is not by use of an injunction enforcing claims for future amounts that the defendant still has the right to modify; the injunction's sanction does not take effect for any particular payment until it becomes due, at which time the defendant loses his right to seek modification under a prospectively modifiable decree. ${ }^{78}$ At any time it remains open to the defendant to initiate modification hearings in state courts for subsequent payments. Because enforcement by injunction does not levy a federal sanction against a defendant until a payment is no longer modifiable, it does not run afoul of the defendant's due process right under Griffin.

\section{B. Federalism}

Erie and considerations of federalism yield precisely the same results. ${ }^{74}$ Federal courts are limited, under Erie, in the ways in which they can apply state law. According to one statement of the doctrine:

[i]n all cases where a federal court is exercising jurisdiction solely because of the diversity of citizenship of the parties, the outcome of the litigation in the federal court should be substantially the same, so far as legal rules determine the outcome of a litigation, as it would be if tried in a State court. ${ }^{76}$

In other words, federal judges applying state law should act as the

\footnotetext{
U.S. at 183-85.

${ }^{71}$ See supra text accompanying notes 63-64.

72 See, e.g., Harrison v. Harrison, 214 F.2d 571, 573-74 (4th Cir.), cert. denied, 348 U.S. 896 (1954).

73 This conclusion assumes that enforcement in federal court would be made subject to modification in state court, as in Keating.

76 For a discussion of the view that the Erie doctrine is the federal version of due process restrictions on a state's conflict of law choices, see D. CurRIs, FEDERar CourTs 395 (3d ed. 1982) ("In short, is not Erie an application of the principle that a disinterested forum may not frustrate the policies of an interested state?"). See also Weintraub, The Erie Doctrine and the State Conflict of Laws Rules, 39 IND. L.J. 228, 238-41 (1964) ("[A] constitutional argument for Erie can be made by analogy to those cases establishing due process limitations on a state's choice of law.").
}

75 Guaranty Trust Co. v. York, 326 U.S. 99, 109 (1945). 
state courts would act. ${ }^{76}$ This might suggest that if a defendant can argue for modification in state court but not in federal court, the outcome is liable to be substantially different, and hence if modification is not possible in federal courts, enforcement of modifiable decrees should not be possible either.

It is not always the case, however, that if a defendant can argue for modification in state courts but not in federal courts, the outcome is likely to be substantially different. For example, when a court considers both future and past-due payments under a prospectively modifiable decree, enforcement and modification concern fundamentally different issues, even if they are considered in the same hearing; the outcome on one issue does not affect the outcome on the other. Enforcement will concern only amounts that have already accrued; modification will concern only future payments. The two amounts are independent and do not overlap: Since the two results are separable, there is no Erie reason why a federal court may not consider the former without the latter. There will be no substantial difference in outcome; a judgment in federal court as to past-due payments will be no different from the judgment the defendant would have gotten in state court. Modification will have no effect on the amount adjudged due at the enforcement hearing, and the defendant will still be able to ask for modification in state court. To deprive federal courts of jurisdiction over the enforcement hearing because they have no jurisdiction over the modification would make no more sense than depriving them of jurisdiction in one action because they had no jurisdiction in a totally unrelated action simply because state courts had discretion to join the two in one hearing.

In the case of future enforcement of alimony and support, the existence of Erie problems, like the existence of due process problems, depends greatly on the remedy. If the plaintiff has requested a bond, then the scope of the modification hearing and the scope of the enforcement hearing are the same; the outcome of one would affect the outcome of the other because modification might affect the size of the bond, or indeed whether there was any bond needed at all, given the possibility that the defendant might be relieved of all future obligation. A federal court that could not hear a modification plea ought not to hear the enforcement plea. ${ }^{77}$ But

${ }^{36}$ D. CurRIe, supra note 74, at 397. But cf. Nolan v. Transocean Air Lines, 276 F.2d 280 (2d Cir. 1960) (New York federal court applied California law to suit in which New York state court would have applied South Carolina law).

${ }^{77}$ See supra text accompanying notes 54-74. 
if the remedy in question is an injunction with contempt for noncompliance, enforcement will be of each payment as it comes due and becomes vested. Enforcement by injunction is thus closely analogous to enforcement of payments past due. ${ }^{78}$ Modification will not affect the outcome of the enforcement hearing, since the contempt-of-court sanction enforcing payment will not attach until payments are past-due and hence no longer modifiable. ${ }^{79}$ Where a federal court enforces future payments under prospectively modifiable decrees with an injunction, the same result follows on both due process and Erie grounds: the federal court may hold an enforcement hearing without a hearing on modification.

\section{Custody}

In 1982 the United States Courts of Appeals for the District of Columbia and Seventh Circuits reached similar results in two cases involving the taking of a child by one parent in violation of a custody decree: Lloyd $v$. Loeffler ${ }^{80}$ and Bennett $I I^{81}$ In each case, the federal district court had been asked for damages for past injury because of the violation ${ }^{82}$ and forward-looking relief that would take the form of an injunction against continued deprivation of custody in one case and continuing punitive damages for the continuing tort in the other. ${ }^{83}$ In each case, the court of appeals affirmed the damage award for past injury, but concluded that the requested forward-looking relief was within the domestic relations exception. ${ }^{84}$

The policy considerations that bear on the scope of the exception in child custody cases are essentially identical to those relevant to alimony and support decrees. In general, it does not violate

78 I am assuming as in note 73 that the injunction is made subject to modification in state courts.

78 A third method of enforcement was used in Lloyd v. Loeffler, 694 F.2d 489 (7th Cir. 1982), a child custody case: continuing punitive damages. For purposes of the due-process and federalism analyses of this comment, continuing punitive damages are indistinguishable from an injunction. See infra text accompanying notes 116-17.

so 694 F.2d 489 (7th Cir. 1982).

31682 F.2d 1039 (D.C. Cir. 1982).

2694 F.2d at 491; 682 F.2d at 1041.

es 694 F.2d at 491 (punitive damages); 682 F.2d at 1041 (injunction).

s4 See Lloyd, 694 F.2d at 493-94; Bennett II, 682 F.2d at 1040-41. In Bennett II, id. at 1044 , in which the injunction was sought, the court ruled that the district court did not have jurisdiction. In Lloyd, 694 F.2d at 493, the Seventh Circuit held that since the concerned party was not before the court of appeals to raise the issue of jurisdiction over the continuing damage award it could not decide the issue. Nevertheless, in a lengthy dictum the court explained that the district court did not have such jurisdiction. 
either principles of federalism or the due process rights of the defendant under Griffin $^{85}$ to allow federal courts to enforce state custody decrees. What additional considerations there are pertaining peculiarly to child custody also militate against a broad exception to jurisdiction. Finally, the awarding of damages in tort by both courts, in lieu of direct enforcement by injunction, is inappropriate; due-process and federalism considerations will allow such damages only where direct enforcement would also be available.

\section{A. The Enforcement of Custody Decrees}

1. Due Process and Federalism. As in the case of alimony and support, the policies underlying an exception to diversity jurisdiction for suits to enforce custody decrees boil down to two: due process and federalism. ${ }^{86}$ The due process issue was described by the Second Circuit in Hernstadt v. Hernstadt. ${ }^{87}$

As the decree sought to be enforced is one subject to modification, if appellant were to be permitted to prosecute this suit, the federal courts would inevitably be entitled to reexamine the Connecticut decree in the light of whatever changed circumstances might be alleged. In fact a strong argument can be made to the effect that the wife here would be deprived of due process of law if a court which assumed jurisdiction over such a dispute refused to reexamine the merits of the original decree. But it is just this reexamination in custody matters which is barred from the federal courts by In re Burrus. ${ }^{88}$

If jurisdiction without an examination of the merits is a denial of due process, and if federal courts are prohibited from examining the merits, then a federal court that took jurisdiction would violate the parties' due process rights. However, just as the apparent inextricability of enforcement and modification of alimony and support awards proves on closer examination to be largely illusory, ${ }^{89}$ so too may federal courts in most cases enforce custody decrees without

\footnotetext{
8s See supra text accompanying notes $63-64$.

se See supra text accompanying notes $43-51$.

${ }^{87} 373$ F.2d 316 (2d Cir. 1967).
}

s Id. at 318 . In a footnote to this passage, the court cites as "an analogous situation" the case of Worthley v. Worthley, 44 Cal. $2 \mathrm{~d} 465$, 283 P.2d 19 (1955). See 373 F.2d at 318 n.1. In Worthley, Justice Traynor's opinion illustrates the dilemma Griffin created for states, that like California, had undertaken to enforce the decrees of sister states: they must either try modification on the merits or refuse to enforce. See 44 Cal. $2 d$ at 467-74, 283 P.2d at 21-25. See also Biewend v. Biewend, 17 Cal. 2d 108, 109 P.2d 701 (1941).

Bo See supra notes $53-80$ and accompanying text. 
violating the defendant's due process right to a modification hearing. Like prospectively modifiable money allowances, custody by its very nature cannot be modified in retrospect..$^{90}$ Since custody decrees are by their nature only prospectively modifiable, enforcing a custody decree does not give the plaintiff something to which his rights might later be contested and does not deprive the defendant of any right to contest custody for any future period.

The courts have observed that custody is essentially different from "mere dollars and cents." Nevertheless, enforcing custody decrees finds an analogy in the enforcement of monetary awards through injunctions. Neither an injunction nor enforcing custody gives a parent something to which his or her right might later be contested. Like an injunction, returning custody to the appropriate parent does not give that parent an undue advantage in future modification hearings. If the decree is enforced, the parties are simply put into the positions they were in before the abduction, and the defendant may then argue for modification in state court. ${ }^{22}$

Furthermore, it is the intent of the Uniform Child Custody Jurisdiction Act (U.C.C.J.A.) that, except in unusual cases, states enforce without modification the modifiable decrees of sister states. $^{.3}$ Where compassion and concern for the child dictate it,

- State custody decrees are in fact always modifiable in the courts in which they were issued. H. Clark, The Law of Domestic Relations in the United States \& 17.7, at 598 (1968).

'1 Bennett I, 3 F. Cas. 212, 220 (D.C.D. Or. 1867) (No. 1318).

92 Many state courts will not hear a plea for modification until the abducted child is returned to the proper parent. See, e.g., In re Marriage of Marks, 96 Ill. App. 3d 360, 420 N.E.2d 1184 (1981); West v. West, 125 Ill. App. 2d 251, 261 N.E.2d 31 (1970).

is See S. Katz, Chind Snatching: The Legal Response to the Abduction of Children 89 (1981) (Under the U.C.C.J.A., "[i]f the second state cannot exercise jurisdiction to modify a previous decree, it follows logically that it will enforce the previous decree in a habeas corpus action and return the child.") According to the Commissioner's Prefatory Note to U.C.C.J.A., 9 U.L.A. 111, 114 (1979), "[t] order into the existing chaos. It limits custody jurisdiction to the state where the child has his home or where there are other strong contacts with the child and his family. . . . It provides for the recognition and enforcement of out-of-state custody decrees in many instances . . . . Jurisdiction to modify decrees of other states is limited by giving a jurisdictional preference to the prior court under certain conditions." See also Parental Kidnapping Prevention Act of 1980, § 8(a), 28 U.S.C. \& 1738A (Supp. V 1981):

(a) The appropriate authorities of every State shall enforce according to its terms, and shall not modify except as provided in subsection (f) of this section, any child custody determination made consistently with the provisions of this section by a court of another State.

(f) A court of a State may modify a determination of the custody of the same child made by a court of another State, if-

(1) it has jurisdiction to make such a child custody determination; and (2) the 
federal courts can easily accommodate the unusual case by allowing a period, before enforcement, during which an appeal for modification can be made in state court. ${ }^{94}$ So long as enforcement does not prejudice the defendant's right to a modification hearing, enforcement does not offend the requirement of due process set down in Griffin.

The principle of federalism underlying the domestic relations exception for alimony and support decrees is also invoked in the custody area in Lloyd $v$. Loeffler. ${ }^{95}$ That opinion points out the strong state interest in keeping certain sorts of custody-related proceedings together. ${ }^{.6}$ If there is such an interest in keeping enforcement and modification together, and if Erie requires that federal courts applying state law act as state courts would act, ${ }^{97}$ it is not possible for federal courts to enforce custody decrees if they are unable to modify them. It is difficult to find a state interest sufficient to compel federal courts to deny jurisdiction. A decision by a state to join such hearings cannot be sufficient to exclude federal jurisdiction. If it were, a state could arbitrarily defeat diversity jurisdiction in any particular area by requiring proceedings in that area to be joined with proceedings in an area from which the federal courts were legitimately excluded. A state must advance some justification for wanting the affected actions to be heard together. One possible justification was raised by the Seventh Circuit in Lloyd. It implied that considerations of judicial economy were sufficient justification; if the state court had, for reasons of economy, decided that an action, the tort of abduction of a child, had to be heard in a proceeding ancillary to a custody proceeding, federal courts would not have jurisdiction over the tort proceeding. ${ }^{98}$

In fact there is little support for the assertion of an important state interest in keeping enforcement and modification together. The Lloyd opinion itself does not find such an interest in judicial economy. The U.C.C.J.A. is evidence of a rather strong state interest in the finality of state custody decrees; although the Act does

court of the other State no longer has jurisdiction, or it has declined to exercise such jurisdiction to modify such determination.

a Such a stay would seem to fall under the proposal in AMERICAN LAw INSTITUTE, Study of the Division of Jurisdiction Between State \& Federal Courts § 1371(c) (1969) ("A district court may stay an action . . . on the ground that the action presents issues of State law that ought to be determined in a State proceeding . . . .").

${ }^{95} 694$ F.2d 489 (7th Cir. 1982).

se See id. at 493.

${ }^{97}$ See supra notes 74-76 and accompanying text.

98 See 694 F.2d at 493 . 
allow modification under some circumstances in sister states, its intention is clearly to encourage enforcement without modification and to require the non-custodial parent to seek change in the courts of the original state whenever possible. ${ }^{99}$ Modification becomes possible in a second state only when specified requirements for jurisdiction have been met, ${ }^{100}$ but enforcement need not wait upon modification or upon the shift in jurisdiction. ${ }^{101}$ The U.C.C.J.A. evinces a preference by the states to have their decrees enforced uniformly while reserving to themselves the right to modify. Enforcement of custody decrees in federal courts creates no Erie problems, ${ }^{102}$ since a federal court that entertained an enforcement action without a hearing on modification would be acting as any state court would under the U.C.C.J.A. ${ }^{103}$

2. The Interest of the Child. In Lloyd $v$. Loeffler, ${ }^{104}$ the decla-

20 See S. Katz, supra note 93, at 4, 5; Commissioner's Prefatory Note to U.C.C.J.A., 9 U.L.A. 111, 113-14 (1979). See also Lehman v. Lycoming County Children's Servs. Agency, $102 \mathrm{~S}$. Ct. 3231, 3238 (1982) (speaking of the "exceptional need for finality in child-custody disputes").

${ }^{100}$ U.C.C.J.A. $\S 8,9$ U.L.A. at 142; § 14, 9 U.L.A. at 153.

101 Section 13 of the Act allows enforcement in sister states even when modification is not possible. See U.C.C.J.A. § 13, 9 U.L.A. 111, 151 (1979). The adoption of the Act by 45 states, see U.C.C.J.A., 9 U.L.A. 111 (1979) \& id. at 15 (Supp. 1983) (table of jurisdictions that have adopted Act), is the clearest possible evidence that states do not take it to be in their interest to tie proceedings on enforcement of their decrees in foreign courts to proceedings on modification. See U.C.C.J.A. §§ 13, 14, 9 U.L.A. 151-58 (1979); see also Commissioner's Notes to U.C.C.J.A. § 13, 9 U.L.A. 151 (1979) ("This section, and sections 14 and 15 are the key provisions which guarantee a great measure of security and stability of environment to the 'interstate child' by discouraging relitigations in other states."); Annot., 96 A.L.R.3D 968 (1980) (collecting cases on validity of U.C.C.J.A.).

${ }^{102}$ Allowing federal courts to enforce custody decrees without a modification hearing does not run counter to the holding in Burford v. Sun Oil Co., 319 U.S. 315 (1943). Under Burford, the federal courts are required to abstain from reviewing the decisions of state agencies where the legislature has expressly given exclusive appellate jurisdiction to state courts to avoid the confusion of multiple and conflicting review. Id. at 326-27. In the case of enforcement suits in federal courts, no danger of conflicting review exists, since federal courts are limited to the issue of enforcement alone. Furthermore, the U.C.C.J.A., adopted as of January 1, 1983 by 45 states, see supra note 101, expressly belies the grant of exclusive jurisdiction that is a prerequisite to Burford abstention by providing for enforcement of custody decrees in foreign states. U.C.C.J.A. $\$ 12,9$ U.L.A. at 149-50; U.C.C.J.A. $\$ 13,9$ U.L.A. at 151; Commissioner's Prefatory Note to U.C.C.J.A., 9 U.L.A. at 113-14.

${ }^{10 s}$ In any event, all concern for the interests of the child, the offending parent, and the state of the original decree can be easily satisfied by subjecting all enforcement orders issuing from a federal court to a temporary delay during which the offending parent will have the right to seek modification in a state court. Whereas a refusal to enforce indicates to the parent guilty of child-snatching that he may not have to take any other action to maintain custody, thus defeating the purposes of the original decree, a conditional enforcement order would bring the weight of a federal court to bear in forcing him to decide between returning the child and seeking a reevaluation of the decree in court.

104 694 F.2d 489 (7th Cir. 1982). 
ration that enforcement was outside the jurisdiction of federal courts seems to have been based neither on due process nor on Erie considerations, but rather on concern for the welfare of the child involved. The court was concerned that to enforce an injunction would be "implicitly to answer the question who should have custody of [the child] today."10s Noting the inability of federal courts to determine where the child is better off, ${ }^{106}$ it concluded that to enforce without a hearing on modification would be to make a decision about custody that is liable to do great harm. ${ }^{107}$

On closer examination, concern for the child's welfare points to the opposite conclusion. To refuse to enforce is also to make a decision about custody that can affect the child's welfare. From the point of view of a court ignorant of the circumstances, this decision is as likely to do harm as the prior one: it leaves the child with the offending parent. ${ }^{108}$ Indeed it is probable that harm will be done more often by leaving the child with the abductor. ${ }^{109}$ The decree of the state court is some evidence of this; at one time, at least, a competent court decided against placing the child with the abducting parent. Certainly circumstances change, but it is arguable that in most cases they will not have changed sufficiently to make the abductor the preferable parent. The fact that the defendant chose to abduct the child rather than sue for modification indicates that in fact things have not changed; it may also indicate serious instability. Moreover, the child may be forced to lead the life of a fugitive under the shadow of a state decree, even if that decree is not enforceable. ${ }^{110}$ These arguments do not prove that the child will

10 Id. at 494.

${ }^{108}$ See id. at 492.

107

It is three years since Carol was abducted. She is now four and a half years old. She probably does not remember her father. No matter how egregiously the McMahans have behaved, it might be a terrible thing today to wrench Carol from their custody to return her to her father....

Id. at 494 .

${ }^{108}$ In Lloyd, in light of the fact that the child had been with the offending parent most of her life (a circumstance the court by its owm reasoning was not competent to investigate), there arguably was some chance that the child would be better off with the offending parent. This is probably the exception that proves the rule.

109 This explains the strong preference of the U.C.C.J.A. for finality of decrees. See supra note 99 and accompanying text.

110 The plaintiff may well not have any remedy outside the federal court because of the need to obtain personal jurisdiction over the abductor. In Bennett $I I$, the court conceded that the plaintiff might not have any other forum. 682 F.2d at 1043. See also Lloyd v. Loeffler, 694 F.2d at 493 ("[A] Maryland court might not be able to obtain personal jurisdiction over the Loefflers....."). 
always be better off with the parent who has legal custody; but if the child's welfare is the main concern in these cases, then a court that cannot investigate changing conditions (as federal courts cannot), and thus must act in ignorance of such changes, will further the child's welfare more often by enforcing existing state custody decrees than by refusing to enforce them.

Custody decrees should therefore be enforceable in federal courts. As Judge Edwards said in his dissent to Bennett II, "Enforcement of a valid and final state decree does not require a federal court to inquire into the present best interests of minor children; rather, the federal court need only give effect to the binding decision of. a state court."111

\section{B. Enforcement of Custody Through Damage Awards}

Bennett II and Lloyd v. Loeffler ${ }^{12}$ are examples of the recent tendency to try to enforce custody decrees indirectly by getting large damage awards from the courts. ${ }^{113}$

The consequences after an abduction of awarding damages but not enforcing custody are both odd and inefficient. The dissent in Bennett II, pointing out that a plaintiff could return as often as he liked for new damage awards but could never get enforcement of custody, called the result a "child-rental" arrangement. ${ }^{114}$ As long as the abducting parent was willing to pay damages, the majority had no apparent objection to letting the child stay with her. More frequently, as the dissent noted, the defendant in such a case is likely to be judgment-proof, ${ }^{118}$ again rendering damages ineffective.

$111682 \mathrm{~F} .2 \mathrm{~d}$ at 1045 (Edwards, J., dissenting in part, concurring in part).

112 See supra text accompanying notes 80-84.

11 See cases cited supra notes 39-42. The relatively liberal granting of jurisdiction to award damages in child-custody cases is part of a general, though by no means uniform, expansion of jurisdiction over tort and contract actions touching on domestic relations. $C f$. Cole v. Cole, 633 F.2d 1083 (4th Cir. 1980) (duty to abstain from malicious prosecution, abuse of process, arson, and conversion does not arise out of a domestic relationship, even if its breach had its origin in a domestic quarrel); Oxley v. Sweetland, 94 F.2d 33 (4th Cir. 1938) (federal court has jurisdiction where purpose of suit is not to establish the fact of a marriage, even if that is an incidental effect); Spindel v. Spindel, 283 F. Supp. 797 (E.D.N.Y. 1968) (federal courts have jurisdiction to determine the validity of a marriage contract). But see Albanese v. Richter, 161 F.2d 688 (3d Cir.), cert. denied, 332 U.S. 782 (1947) (cause of action appears in the domestic relations section of state laws, hence federal courts have no jurisdiction); Kilduff v. Kilduff, 473 F. Supp. 873 (S.D.N.Y. 1979) (federal courts have no jurisdiction over cases originating in a domestic quarrel); Linscott v. Linscott, $98 \mathrm{~F}$. Supp. 802 (S.D. Iowa 1951) (no jurisdiction where a judgment might affect the later domestic relations of the parties).

114 682 F.2d at 1045 (Edwards, J., dissenting in part, concurring in part).

118 Id. at 1045 n.2. 
Even if the defendant is neither judgment-proof nor so wealthy as to make him indifferent to payment of damages, the awarding of a single lump sum as payment for past damages fails to provide the defendant with any incentive to return the child, since the amount owed is independent of the parent's compliance with the court's order.

Prior to an abduction, the prospect of damages is unlikely to be a deterrent. This is clearly so if the parent is judgment-proof. Even if he is not, he may refuse to compare custody of the child with monetary loss. While a reasonable parent, in a reasonable mood, might be unwilling to pay hundreds of thousands of dollars to reacquire custody of a child awarded to the other parent, the same may not be true of a parent who faces the prospect of damages in that amount for child abduction.

While punitive damages for the continued holding of the child give the abductor an incentive to return the child, they raise all the supposed jurisdictional problems of direct enforcement. ${ }^{116}$ Continuing punitive damages resemble direct enforcement and are unlike lump-sum damages in that they implicate the future status of the child. Punitive damages that continue until the defendant relinquishes the child involve precisely the same intrusion into state interests in domestic relations and the same abridgement of the defendant's due process right to a modification hearing as does any federal enforcement of a prospectively modifiable decree. ${ }^{117}$ Wherever punitive damages are within the jurisdiction of the federal courts, so is direct enforcement by injunction.

\section{ConcLusion}

The domestic relations exception may be seen as an expression of the principle that federal jurisdiction does not extend into areas of strong state interest. Because of this principle, federal courts do not grant divorces, allowances for alimony or support, or custody. But where the rights, duties, and obligations have been created by state courts, federal courts can, in the exercise of their diversity jurisdiction, enforce them. Where modifiable state decrees are in question, the jurisdiction of the federal courts is limited to some extent by considerations of due process and federalism. There is no

${ }^{116}$ See Lloyd v. Loeffler, 694 F.2d at 493-94, where the court declined both to enforce a state custody decree directly and to award continuing punitive damages on the same ground: either would require an investigation into domestic circumstances that the federal courts are incompetent to make.

11 See supra notes 65-74 and accompanying text. 
convincing objection, however, to the enforcement of alimony or support decrees that are not retrospectively modifiable, nor to the enforcement of state custody awards. The recent practice of enforcement of custody decrees through damage awards, however, raises genuine problems of due process and federalism, and hence should be abandoned.

Michael L. Corrado 